\title{
Right ventricular hypertrabeculation due to right heart failure after left ventricular assist device implantation
}

\author{
Christina Maria Steger, ${ }^{1,2}$ Susanne Reinold ${ }^{1}$ \\ ${ }^{1}$ Department of Pathology, Innsbruck Medical University, Innsbruck, Austria \\ ${ }^{2}$ Department of Pathology, Ludwig-Maximilians-University, Munich, Germany
}

Correspondence to Dr Christina Maria Steger, Christina.Steger@med.uni-muenchen.de

\section{DESCRIPTION}

Hypertrabeculation/non-compaction of ventricular myocardium (HVM/NVM) is a cardiomyopathy thought to be caused by arrest of normal embryogenesis of the endocardium and myocardium between the fetal 5 th and 8 th weeks, resulting in persistence of multiple prominent ventricular trabeculations with deep intertrabecular recesses. ${ }^{1}$ The myocardium of the left ventricle is most often affected, but biventricular or right ventricular hypertrabeculation (RVHT) is also possible.

RVHT may be associated with congenital heart disease ${ }^{2}$ and it has also been reported that RVHT could possibly present as an isolated ${ }^{3}$ or acquired disease. ${ }^{4}$
Clinical manifestations are highly variable, ranging from no symptoms to disabling congestive heart failure, arrhythmias, systemic thromboemboli and sudden death.

A 61-year-old man had a prior medical history of myocardial infarction in 1999 and underwent two-vessel coronary artery bypass grafting in 2000 (left internal mammary artery to the left anterior descendent artery and the first obtuse marginal branch). A biventricular pacemaker with defibrillator (CRT-D) due to advanced chronic heart failure was implanted in February 2010.

Owing to the worsening ischaemic cardiomyopathy and recurrent cardiac decompensation, he received a left ventricular assist device (LVAD) as bridge-to-transplant
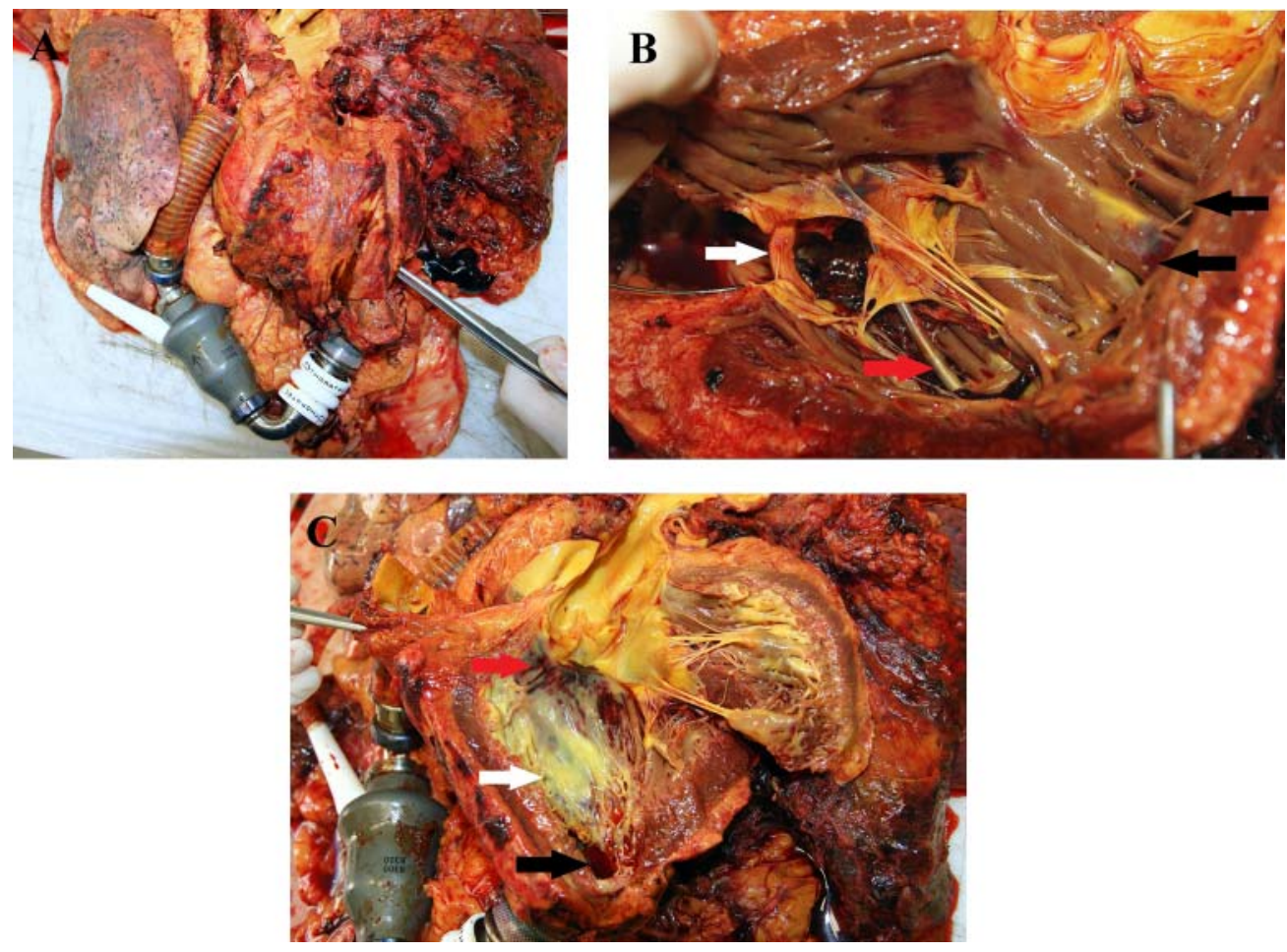

Figure 1 (A) The patient's heart with the left ventricular assist device (LVAD) implantation bypassing the left ventricle. (B) Right ventricle with right ventricular hypertrabeculation (black arrows), electrodes of the implantable biventricular pacemaker with defibrillator (red arrow) and tricuspid valve repair using the Carpentier-Edwards physio tricuspid annuloplasty ring (white arrow). (C) The left heart with the LVAD apex inflow cannula (black arrow), and the extended anteroseptal myocardial infarction (white arrow) with subendocardial haemorrhage below the aortic valve cusps (red arrow). 


\section{BMJ Case Reports}

concept with a tricuspid valve repair in August 2011. Preoperative echocardiographic examination revealed a grade II tricuspid valve insufficiency, a right heart and left atrial dilation, but no RVHT.

Postoperatively, he suffered from right heart decompensation and a peripheral extracorporeal membrane oxygenation (ECMO) was implanted to temporarily assist circulation. After ECMO explantation high-dose catecholamines were necessary for circulation support. Once again he suffered from right heart failure decompensation with elevated liver enzymes : aspartate aminotransferase (AST) $1526 \mathrm{U} / 1$, alanine aminotransferase (ALT) $596 \mathrm{U} / 1$, lactate dehydrogenase (LDH) $2242 \mathrm{U} / \mathrm{l}$. The patient died 2 weeks after LVAD implantation due to multiorgan failure (figure 1).

At autopsy, the heart showed a right atrial and ventricular dilatation, RVHT, a concentric left ventricular hypertrophy and an acute and old anteroseptal myocardial infarction with subendocardial haemorrhage. The coronary artery bypass grafts were patent.

\section{Learning points}

- Right ventricular hypertrabeculation or non-compaction (RVHT) refers to a structural defect in the right bottom chamber resulting in the development of multiple prominent ventricular trabeculations.

- It can be associated with congenital heart disease (Ebstein's malformation) and has also been described as an acquired disease.

- RVHT can be diagnosed by echocardiographic examination. Clinical symptoms include arrhythmias, heart failure and sudden death.

\section{Competing interests None}

Patient consent Obtained.

\section{REFERENCES}

1. Weiford BC, Subbarao VD, Mulhern KM. Noncompaction of the ventricular myocardium. Circulation 2004;109:2965-71.

2. Song ZZ. A combination of right ventricular hypertrabeculation/ noncompaction and Ebstein's anomaly. Int J Cardiol 2010;143:e30-3.

3. Song ZZ. An isolated right ventricular hypertrabeculation and dyskinesia in an elderly man: a possible diagnosis of isolated right ventricular noncompaction? Int J Cardiol 2011;148:e3-6.

4. Song ZZ. A combination of right ventricular hypertrabeculation/ noncompaction and atrial septal defect. Int J Cardiol 2011;148:e25-7.

This pdf has been created automatically from the final edited text and images.

Copyright 2012 BMJ Publishing Group. All rights reserved. For permission to reuse any of this content visit http://group.bmj.com/group/rights-licensing/permissions.

BMJ Case Report Fellows may re-use this article for personal use and teaching without any further permission.

Please cite this article as follows (you will need to access the article online to obtain the date of publication).

Steger CM, Reinold S. Right ventricular hypertrabeculation due to right heart failure after left ventricular assist device implantation. BMJ Case Reports 2012;10.1136/bcr-2012-006553, Published XXX

Become a Fellow of BMJ Case Reports today and you can:

- Submit as many cases as you like

- Enjoy fast sympathetic peer review and rapid publication of accepted articles

- Access all the published articles

- Re-use any of the published material for personal use and teaching without further permission

For information on Institutional Fellowships contact consortiasales@bmjgroup.com

Visit casereports.bmj.com for more articles like this and to become a Fellow 